\title{
Characterization of powder from the permeate of yacon extract by ultrafiltration and dehydrated by spray drying
}

\section{Caracterização de pó do permeado do extrato de yacon obtido por ultrafiltração e desidratado por atomização}

\author{
Marcela Lazzare Brites ${ }^{1}$, Stela Meister Meira ${ }^{1}$, Adriano Brandelli', Caciano Zapata Noreña ${ }^{1 \star}$ \\ ${ }^{1}$ Universidade Federal do Rio Grande do Sul/UFRGS, Instituto de Ciência e Tecnologia de Alimentos, Porto Alegre, RS, Brasil \\ ${ }^{*}$ Corresponding author: czapatan@ufrgs.br \\ Received in April 8, 2016 and approved in June 27, 2016
}

\begin{abstract}
Yacon root is a functional food which contains antioxidants and prebiotics compounds. This study aimed to evaluate the physical, chemical and prebiotic characteristics of a yacon extract powder obtained by ultrafiltration (UF) with membranes of 10 and $30 \mathrm{kDa}$ and encapsulation of the resulting permeate by spray drying. Drying air temperatures of 140 and $160^{\circ} \mathrm{C}$ and concentrations of gum arabic of 10 and $15 \%$ were tested. The samples had solubility values greater than $90 \%$ while the hygroscopicity decreased with increasing gum concentration and drying temperature. Electron microscopy showed a strong tendency to agglomeration of smaller particles around the larger ones, mainly at a temperature of $140{ }^{\circ} \mathrm{C}$. Regarding color, the parameter $L^{*}$ showed that drying at $160^{\circ} \mathrm{C}$ produced darker samples and the parameters $a^{*}$ and $b^{*}$ indicated that all samples were greenish yellow. The concentration of inulin decreased during drying, whereas the levels of glucose and fructose increased due to the thermolysis reaction, which led to degradation of inulin chains at drying temperature. The permeates and retentates from the UF membranes had prebiotic activity, while only the encapsulated product from UF-30 membrane, metabolized by Lactobacillus acidophilus LA- $5^{\circledR}$, presented activity scores without significant difference to that of glucose.
\end{abstract}

Index terms: Encapsulation; inulin; prebiotic activity.

\begin{abstract}
RESUMO
O yacon é uma raiz que contém compostos com atividade antioxidante e prebiótica. Este estudo teve como objetivo avaliar as características físicas, químicas e prebióticas das micropartículas de yacon encapsuladas por atomização. A partir do extrato do yacon foram obtidas as soluções de retido e permeado usando a separação por ultrafiltração (UF) com membranas de 10 e $30 \mathrm{kDa}$. O permeado foi misturado com goma arábica em concentrações de 10 e $15 \%$ e encapsulado por atomização a temperaturas de 140 e $160^{\circ} \mathrm{C}$. As micropartículas obtidas tiveram valores de solubilidade maiores que $90 \%$, enquanto que a higroscopicidade diminuiu com o aumento da concentração de goma e da temperatura de secagem. A microscopia eletrônica mostrou uma forte tendência à aglomeração de partículas menores em torno das maiores, principalmente a $140^{\circ} \mathrm{C}$. Em relação à cor, o parâmetro $L^{*}$ mostrou que a secagem a $160^{\circ} \mathrm{C}$ produziu amostras mais escuras, e os parâmetros $a^{\star}$ e $b^{*}$ indicaram que todas as amostras tiveram coloração amarelo esverdeado. A concentração de inulina diminuiu durante a secagem, enquanto que os conteúdos de glicose e de frutose aumentaram devido às reações de termólise, o que levou à degradação das cadeias de inulina. As dispersões permeadas e retidas provenientes da separação de UF apresentaram atividade prebiótica, enquanto que somente o pó encapsulado proveniente da membrana de $30 \mathrm{kDa}$ foi metabolizado pelo Lactobacillus acidophilus, apresentando escores de atividade sem diferença significativa em relação à da glicose.
\end{abstract}

Termos para indexação: Encapsulação; inulina; atividade prebiótica.

\section{INTRODUCTION}

Yacon is a plant cultivated in many Andean countries, such as Ecuador, Peru and Bolivia (Ojansivu; Ferreira; Salminen, 2011). Yacon roots have agronomic characteristic to be adaptable to several climates and soils. Nowadays, it is cultivated in different countries, such as Japan, Brazil, Australia, Czech Republic, China, and The United States.

Yacon has tubers with a delicious sweet flavour that may be consumed peeled in fruit salads, steamed or fried (Sousa et al., 2015a). The sweet taste is related to its composition rich in carbohydrates, because unlike other tubers, yacon roots stores fructooligosaccharides (FOS) and inulin instead of starch (Franco et al., 2015; Castro, et al., 2013). Commonly, inulin is used as a prebiotic, fat replacer, sugar replacer, texture modifier and for the development of functional foods in order to improve health due to its beneficial role in gastric health (Shoaib et al., 2016). Zhu et al. (2014) studied the activity of polysaccharides from yacon, as natural hypoglycemic agent, due to his inhibitory effect on $\alpha$-glucosidase. Its large tuberous roots have a 
pulp similar to sweet potatoes, with sweet taste due to the abundance of carbohydrates such as fructose, glucose, sucrose, and inulin with a degree of polymerization (DP) up to 12 (Lachman; Fernández; Orsák, 2003), consequently recognized as fructooligosaccharide (FOS). In addition, several researchers have mentioned that the use of the yacon tuber as a functional food is gaining interest because it contains antioxidants. In addition, a high fraction of its dry biomass is composed of FOS, which are inulin-type oligofructans with prebiotic power (Utami et al., 2013). Furthermore, yacon has a large amount of water, more than $70 \%$ of the fresh weight, and its roots do not store carbohydrates as starch, making them potentially beneficial in the diet of individuals with diabetes (Lachman; Fernández; Orsák, 2003). According to Ojansivu, Ferreira and Salminen (2011), the consumption of yacon is recommended for weight control because it has relatively low calorific values. In addition to these health benefits, antioxidant effects have been reported (Takenaka et al., 2003; Sousa et al., 2015b).

FOS are defined as a combination of three sugars, 1-kestose $\left(\mathrm{GF}_{2}\right)$, nystose $\left(\mathrm{GF}_{3}\right)$ and fructofuranosylnystose $\left(\mathrm{GF}_{4}\right)$, in which the fructosyltransferase units $(\mathrm{F})$ are bonded in position $\beta(2 \rightarrow 1)$ from sucrose (GF). They are considered prebiotics because selectively stimulate the proliferation and activity of bifidobacteria and lactobacilli in the gut (Lachman; Fernández; Orsák, 2003), providing an increased resistance to intestinal infections due to production of immunomodulating substances (Matusek et al., 2011; Vaz-Tostes et al., 2014). To maintain these properties, FOS should be chemically stable under heat and $\mathrm{pH}$ treatments (Huebner et al., 2008).

In this way, yacon roots can be used by both pharmaceutic and food industries, in order to obtain products that might be used as food ingredients or supplements, with properties, such as prebiotic, bioactive, low-glycemic sweetener, anti-motility, fiber and appetite suppressing.

Membrane separation process (MSP) has been used in recent years to separate FOS constituents from their natural sources. Kamada et al. (2002a) emphasized that this method has a higher selectivity when compared to other conventional methods of filtration. In addition, it does not use chemicals during separation and it only requires a difference of pressure as the driving force needed, to separate the compounds of interest. Some authors have highlighted the use of MSP in the purification of oligosaccharides present in carbohydrate-rich foods. Kamada et al. (2002b) examined the effect of ultra and nanofiltration in purification and concentration of FOS from yacon root, achieving the removal of most of mono- and disaccharides and obtaining a concentrated product with $98 \%$ purity, presenting molecules with a DP of three or more.

The encapsulation of active components by spray drying became one of the most used methods of coating. The main objective is to form a barrier between the core, consisting of the active components, and the environment, able to protect it from oxygen, light, moisture or contact with other ingredients (Saénz et al., 2009). Encapsulation can avoid or delay changes that may result in losses of flavor, color, or nutritional value (Pszczola, 1998). The process of spray drying is too rapid, with an intensive moisture evaporation at the droplet surface, which keep the droplets cold until the dry state is reached (Ré, 1998). The powder obtained should possess desirable properties such as good handling, mixing capacity with water or other powders, in addition to prevent the loss of volatile components and to extend the life cycle of the product.

Gum arabic is one of the most common wall materials used in microencapsulation by spray drying because it presents characteristics such as high solubility, low hygroscopicity and good emulsifying properties (Carneiro et al., 2013). An important feature of this polysaccharide is to protect the core and permit either slow release of the core material or release after the occurrence of certain disturbance. The controlled release could prevent the ineffective use and loss of compounds during processing (Risch; Reineccius, 1995). In addition, gum arabic is a native source of soluble fiber, with prebiotic effect that provides health benefits, because it has a high digestive tolerance, beneficial impact on the glycemic index of the final product and low calorific value (Ali; Ziada; Blunden, 2009).

Gum arabic has been used in the encapsulation of various products, however there are no publications related to its use in spray drying in combination with inuline. The objective of this study was to evaluate the physical and chemical characteristics of the powder obtained from the permeate of yacon extract ultrafiltrated and then dried by spray drying using gum arabic at two different concentrations and two dry air temperatures.

\section{MATERIALS AND METHODS}

\section{Yacon extract preparation}

The yacon roots were acquired from the Supply Center of the State of Rio Grande do Sul (CEASA, Porto Alegre, Brazil). The roots were washed and selected considering the absence of visual injuries and infections, and stored under refrigeration $\left(8 \pm 1{ }^{\circ} \mathrm{C}\right)$ until the moment of use, for a maximum period of 3 days. Then, the roots were peeled and 
cut into slices with an average diameter of $4.55 \pm 0.25 \mathrm{~mm}$ and thickness of $1.75 \pm 0.35 \mathrm{~mm}$ using a vegetable slicer. This material was subjected to blanching by steam at $100^{\circ} \mathrm{C}$ for 4 $\mathrm{min}$, followed by cooling in an ice bath for $3 \mathrm{~min}$; blanched slices were extracted using a food processor. The pulp obtained after separation of the juice was extracted from the remaining sugars by the addition of water at $80^{\circ} \mathrm{C}$ in a $2: 1$ (weight water/ weight pulp) maintaining the mixture at $80^{\circ} \mathrm{C} \pm 2{ }^{\circ} \mathrm{C}$ for one hour, according to the methodology proposed by Tófano et al. (2007). The yacon juice and liquid solution obtained from the pulp were separately filtered at vacuum pump at a pressure of $400 \mathrm{mmHg}$, using Whatman filter paper $\mathrm{n}^{\circ} 01$. The mixture consisted of filtered extract of yacon was frozen at $-18^{\circ} \mathrm{C}$ until use for a maximum period of two months.

\section{Separation process}

Polymeric ultrafiltration (UF) membranes with nominal molecular weight cut-off 10 (UF-30) and 30 kDaltons (UF-30), made of polyethersulfone (Synder Filtration Headquarters, Vacaville, USA), were employed. The membranes were installed in a module with flat membrane surface area of $0.008118 \mathrm{~m}^{2}$.

The process of UF was carried out at $25{ }^{\circ} \mathrm{C}$ (temperature that provided the best flow in both membranes) recirculating the total of retentate in the feed tank. The UF process was conducted for approximately $6 \mathrm{~h}$, which was the time required for the collection of approximately $200 \mathrm{~mL}$ of permeate. At the end of the process, the permeate and the retentate were separately packaged and frozen at $-18^{\circ} \mathrm{C}$. The permeate samples were used in the process of spray drying because of their greater amount of simple sugars and FOS.

\section{Encapsulation process}

The permeate obtained in the MSP (membrane separation process) was mixed to gum arabic (Nexira Brazil Comercial Ltda., São Paulo, Brazil) at concentrations of 10 and $15 \%(\mathrm{~m} / \mathrm{v}$; mass of gum arabic per volume of yacon permeate) under stirring using Ultra Turrax (IKA/T25) for $4 \mathrm{~min}$ at $6000 \mathrm{rpm}$ until complete dissolution, resulting in dispersions whose total solids content were 10 and $15 \%$, respectively. These dispersions were dehydrated by spray drying, using a Mini-Spray Dryer Model LM 1.0 MSDI (Labmaq, Brazil) with a nozzle diameter of $1.0 \mathrm{~mm}$. The air temperatures used were 140 and $160{ }^{\circ} \mathrm{C}$.

The encapsulated powder was packed in a high density polyethylene bag and kept tightly closed in a desiccator containing silica at room temperature until the time of analysis, for a maximum period of 3 days.

\section{Water activity, solubility and hygroscopicity}

The water activity $\left(\mathrm{a}_{\mathrm{w}}\right)$ of the samples was measured using an analyzer Aqualab 3TE based on the method $n^{\circ}$ 978.18 of Association of Official Analytical Chemists AOAC (1990). The solubility was determined according to the methodology described by Cano-Chauca et al. (2005) with some modifications. The hygroscopicity was determined according to the method proposed by Tonon et al. (2009).

\section{Color parameters}

The color was determined using a Petri dish, and filled to the top with the powdered material through direct reading on a Minolta colorimeter (CR400/410) calibrated with a white ceramic plate $\left(L^{*}=97.47, a^{*}=0.08\right.$ and $b^{*}$ $=1.76)$. The color was measured using the tridimensional CIE $L * a * b *$ system.

\section{Scanning electronic microscopy}

The microstructure of the powders was visualized by scanning electronic microscopy (SEM) using the method recommended by Toneli et al. (2008), which consisted of approximately $1 \mathrm{mg}$ of the different powder samples onto double faced adhesive tape adhered to metallic holders (stubs). Being a powder product, it was necessary to remove excess sample with a manual blower, avoiding loss of the material during visualization. Samples were analyzed after they had been gold sputtered (SCD050; Bal-Tec, New York, USA) and viewed under MEV (JSM 6060, JEOL, Tokyo, Japan) operating at 10 $\mathrm{kV}$ and $1 \times 10^{-6}$ mbar using a magnification of $3000 \times$.

\section{Determination of sugar concentrations by HPLC}

The samples were prepared by an adaptation of the method described by Tófano et al. (2007). Five grams of the sample was ground with $50 \mathrm{~mL}$ deionized water at $90^{\circ} \mathrm{C}$ and the mixture placed in a water bath at $80^{\circ} \mathrm{C}$ with stirring for $1 \mathrm{~h}$. Then, the suspension was cooled to room temperature, filtered through a membrane of $0.22 \mu \mathrm{m}$ and frozen at $-18^{\circ} \mathrm{C}$. In the analysis, the frozen samples were heated to $80^{\circ} \mathrm{C}$ and placed in a sonicator for $3 \mathrm{~min}$ before injection into the HPLC. Analyses were performed by adapting the method described by Zuleta and Sambucetti (2001), which consisted of a direct determination by High Performance Liquid Chromatography (HPLC-RI). A Perkin Elmer Series 200 chromatograph with a refractive index detector was used. Ultrapure water (Milli-Q, Millipore, USA) was the mobile phase at a flow rate of $0.6 \mathrm{~mL} / \mathrm{min}$ at $80^{\circ} \mathrm{C}$. A $300 \times 7.8 \mathrm{~mm}$ Rezex RHM Monosaccharide column (Phenomenex, Torrance, USA) was used and the total run time was $14 \mathrm{~min}$. 


\section{Prebiotic activity assay}

To determine the prebiotic activity, two commercial freeze dried probiotic cultures - Lactobacillus acidophilus LA $-5^{\circledR}$ and Bifidobacterium lactis BB- $12^{\circledR}$, provided by Chr. Hansen (Valinhos, Brazil) - were employed and Escherichia coli ATCC 25922 was used as an enteric culture. The analyses were performed according to the method described by Huebner, Wehling and Hutkins (2007).

For the tests, $0.05 \mathrm{~g}$ of freeze dried probiotic cultures were activated in $10 \mathrm{~mL}$ of Man Rogosa Sharpe broth (MRS, Himedia, India) and incubated at $37^{\circ} \mathrm{C}$ for $24 \mathrm{~h}$. Then, $500 \mu \mathrm{L}$ of LA- 5 and BB-12 cultures were transferred to $10 \mathrm{~mL}$ MRS broth and incubated for 24 h at $37^{\circ} \mathrm{C}$. The bacterium E. coli, kept frozen at $-20^{\circ} \mathrm{C}$ in $20 \%$ glycerol $(\mathrm{v} / \mathrm{v})$, was activated by transferring the aliquot of $100 \mu \mathrm{L}$ to $10 \mathrm{~mL}$ of brain heart infusion (BHI, Oxoid, UK) and incubated at $37^{\circ} \mathrm{C}$ for $24 \mathrm{~h}$. An additional transfer of $100 \mu \mathrm{L}$ to $10 \mathrm{~mL}$ of BHI broth was performed prior to use. The initial bacteria concentrations were approximately $10^{6} \mathrm{UFC} / \mathrm{mL}$.

The tests were performed by placing $1 \%(\mathrm{v} / \mathrm{v})$ of each culture in individual sterile tubes containing MRS broth (LA-5 and BB-12) or BHI broth (E. coli) and adding $1 \%(\mathrm{w} / \mathrm{v})$ glucose (control) or $1 \%(\mathrm{w} / \mathrm{v})$ of samples with and without encapsulation. The prebiotic activity score was determined by cell density (D.C.), which was measured by optical density (D.O) at $600 \mathrm{~nm}$ in UV-visible spectrophotometer (Shimadzu-1240) (Huebner; Wehling; Hutkins, 2007).

\section{Statistical analyses}

All analyses were performed in duplicate and comparison between treatments was carried out by Tukey's means comparison tests. The results were analyzed using the statistical software SAS version 9.3 (SAS Institute Inc.) at $95 \%$ confidence level.

\section{RESULTS AND DISCUSSION}

\section{Water activity, solubility and hygroscopicity}

The $\mathrm{a}_{\mathrm{w}}$ values, measured at room temperature, of samples encapsulated with gum arabic and dehydrated by spray drying under different conditions are shown in Table 1. Regarding $\mathrm{a}_{\mathrm{w}}$, the samples atomized with $10 \%$ gum and temperature of $140{ }^{\circ} \mathrm{C}$ had significantly higher values $(p>0.05)$. The lower values of $\mathrm{a}_{\mathrm{w}}$ were obtained using $15 \%$ gum, not being affected by the temperature used. In addition, for each type of treatment employed, the membrane type used did not significantly affect $a_{w}$.

The values of solubility of the powder from the permeate of yacon extract obtained with UF-10 and UF30 membranes are also presented in Table 1. For the two membranes used, the most significantly soluble samples were those with $15 \%$ gum regardless of the temperature used. An increased solubility was obtained using the highest concentration of gum and drying temperature. The percentage of solubility above $90 \%$ were higher than for yacon juice and concentrate juice powders obtained by foam mat drying in another study, which showed values between 80 and $85 \%$ (Franco et al., 2016).

The highest values for hygroscopicity were obtained when using $10 \%$ gum, regardless of the temperature used (Table 1). With increasing concentration of the encapsulating agent, the hygroscopicity decreased significantly $(p<0.05)$. This is due to the fact that gum Arabic is a material with low hygroscopicity and confirms the efficiency of its use as a carrier agent, reducing the hygroscopicity of dehydrated products in spray dryer (Fazaeli et al., 2012).

According to Roos (1993), the sticky behavior of materials with large quantities of low molecular mass sugars such as glucose, fructose and sucrose is due to the low $T_{\mathrm{g}}\left(31{ }^{\circ} \mathrm{C}, 5^{\circ} \mathrm{C}, 62{ }^{\circ} \mathrm{C}\right.$, respectively). The molecular

Table 1: Water activity (aw), solubility (\%) and hygroscopicity (\%) of the encapsulated powder from the permeate of yacon extract.

\begin{tabular}{ccccccc}
\hline \multicolumn{5}{c}{ UF-10 } & \multicolumn{4}{c}{ UF-30 } \\
\hline Treatment & $\mathrm{a}_{\mathrm{w}}$ & Solubility & Higroscopicity & $\mathrm{a}_{\mathrm{w}}$ & Solubility & Higroscopicity \\
\hline $10 \%, 140^{\circ} \mathrm{C}$ & $0.135 \pm 0.001 \mathrm{a}$ & $90.52 \pm 0.11 \mathrm{c}$ & $17.79 \pm 0.08 \mathrm{a}$ & $0.132 \pm 0.002 \mathrm{a}$ & $90.46 \pm 0.48 \mathrm{~b}$ & $18.08 \pm 0.07 \mathrm{a}$ \\
$15 \%, 140^{\circ} \mathrm{C}$ & $0.094 \pm 0.003 \mathrm{c}$ & $93.38 \pm 0.20 \mathrm{ab}$ & $15.49 \pm 0.18 \mathrm{c}$ & $0.092 \pm 0.001 \mathrm{c}$ & $92.06 \pm 0.14 \mathrm{ab}$ & $15.25 \pm 0.10 \mathrm{c}$ \\
$10 \%, 160^{\circ} \mathrm{C}$ & $0.113 \pm 0.005 \mathrm{~b}$ & $92.98 \pm 0.82 \mathrm{~b}$ & $17.40 \pm 0.08 \mathrm{~b}$ & $0.112 \pm 0.004 \mathrm{~b}$ & $91.20 \pm 0.40 \mathrm{~b}$ & $17.32 \pm 0.05 \mathrm{~b}$ \\
$15 \%, 160^{\circ} \mathrm{C}$ & $0.087 \pm 0.002 \mathrm{c}$ & $95.40 \pm 0.79 \mathrm{a}$ & $14.50 \pm 0.09 \mathrm{~d}$ & $0.085 \pm 0.001 \mathrm{c}$ & $93.48 \pm 0.17 \mathrm{a}$ & $14.35 \pm 0.05 \mathrm{~d}$ \\
\hline
\end{tabular}

Values expressed as mean \pm standard deviation. The same small letters in the same column for $\mathrm{a}_{\mathrm{w}^{\prime}}$ solubility and higroscopicity indicate no significant difference $(p>0.05)$. 
mobility of these compounds is high when the temperature of the spray-dried particle is $20^{\circ} \mathrm{C}$ above the $T_{\mathrm{g}}$ (Bhandari; Data; Howes, 1997). In addition, the component sugars of FOS $\left(\mathrm{GF}_{2}, \mathrm{GF}_{3}, \mathrm{GF}_{4}\right)$ present in yacon can suffer hydrolysis at high temperatures, resulting in low molecular mass monomers, contributing to the effect of sticky powder. Zimeri and Kokini (2002) mention that the use of the encapsulating agents of high molar mass before the drying process causes the $T_{\mathrm{g}}$ increases, facilitating drying and subsequent storage of the powders. Franco et al. (2016) reported values of higroscopicity between 18 and $23 \%$ for yacon juice and concentrate juice powders obtained by foam mat drying.

\section{Color parameters}

With respect to the $L^{*}$ parameter (Table 2), brightness decreased significantly $(p<0.05)$ with the increase of temperature, for membranes of 10 and $30 \mathrm{kDa}$. The presence of reducing sugars in the samples resulted in a greater influence of the Maillard reaction, resulting in darker samples. This type of change in processed foods is related to the type and amount of carbohydrates (mainly sugars) present in foods, which result in the formation of dark pigments called melanoidins (Vega-Gálvez et al., 2009). At higher temperatures, degradation occurs by thermolysis of long-chain inulin, in small compounds such as glucose, fructose and sucrose, and other low molecular mass products as di-D-fructose dianhydrides (DFDAs) (Böhm et al., 2005; Böhm; Kleessen; Henle, 2006). Matusek et al. (2011) reported that the concentration of monomers increased with increasing temperature. They also verified the rapid formation of dimers at 70 and $80^{\circ} \mathrm{C}$ due to the degradation of oligomers of higher DP.

Quek, Chok and Swedlund (2007) showed that the parameter $L^{*}$ decreases with increasing inlet air temperature of $145-175^{\circ} \mathrm{C}$ during spray drying of watermelon juice, while the presence of sugars contributed to the darkening of the powder with increasing temperature. It was observed that samples subjected to the same temperature, but with different concentrations of gum arabic (10 and 15\%), showed no significant difference $(p>0.05)$.

With respect to the parameter $a^{*}$, the powder samples from UF-10 membrane were significantly different from each other $(p<0.05)$, noting that there was interaction between the concentration of gum arabic and the inlet air temperature. For UF-30 membrane, the $a^{*}$ value obtained at $10 \%$ gum and $160{ }^{\circ} \mathrm{C}$ was significantly higher than values obtained for the other treatments (Table 2), evidencing that temperature had a diverse effect for each concentration used. All treatments resulted in greenish samples, which were significantly higher in samples obtained in UF-10 and dehydrated at $140^{\circ} \mathrm{C}$. For the parameter $b^{*}$ (Table 2 ), there was a significant effect of concentration and temperature when considering powder samples from the UF-10. The samples were yellowish and the value was significantly higher $(p<0.05)$ for the sample UF-30, with $15 \%$ encapsulant and $160^{\circ} \mathrm{C}$.

\section{Determination of sugars}

The initial concentrations of inulin, glucose and fructose in the UF-10 permeate were $9.88 \pm 0.08,11.40$ $\pm 0.08,13.24 \pm 0.06 \mathrm{~g} \mathrm{~L}^{-1}$ respectively, and $8.06 \pm 0.01$, $12.35 \pm 0.08,15.60 \pm 0.05 \mathrm{~g} \mathrm{~L}^{-1}$ for the UF-30 permeate. The higher content of inulin in the permeate from UF-10 was probably influenced by the pore size of the membrane, that retained a greater amount of solids with molecular masses greater than sugars. During drying process at high temperatures, thermolysis of inulin to their mono- and disaccharides and other low molecular mass constituents can occur. Another important issue of the dehydration process is water removal, resulting in a high concentration of sugars in the final product. The concentrations of inulin, glucose and fructose in the spray dried permeate of yacon extract are presented in Table 3.

Table 2: Color parameters $L^{*}, a^{*}$ and $b^{*}$ of encapsulated powder from the permeate of yacon extract.

\begin{tabular}{rcccccr}
\hline \multirow{2}{*}{ Treatment } & \multicolumn{3}{c}{ UF-10 } & \multicolumn{3}{c}{ UF-30 } \\
\cline { 2 - 7 } & $L^{*}$ & $a^{*}$ & $b^{*}$ & $L^{*}$ & $a^{*}$ & \multicolumn{1}{c}{$b^{*}$} \\
\hline $10 \%, 140{ }^{\circ} \mathrm{C}$ & $93.85 \pm 0.06 \mathrm{a}$ & $-3.20 \pm 0.03 \mathrm{~d}$ & $11.60 \pm 0.03 \mathrm{a}$ & $93.65 \pm 0.06 \mathrm{a}$ & $-2.66 \pm 0.06 \mathrm{~b}$ & $10.58 \pm 0.21 \mathrm{~b}$ \\
$15 \%, 140^{\circ} \mathrm{C}$ & $93.89 \pm 0.04 \mathrm{a}$ & $-2.98 \pm 0.01 \mathrm{C}$ & $11.36 \pm 0.02 \mathrm{~b}$ & $93.78 \pm 0.25 \mathrm{a}$ & $-2.68 \pm 0.03 \mathrm{~b}$ & $9.91 \pm 0.02 \mathrm{c}$ \\
$10 \%, 160^{\circ} \mathrm{C}$ & $92.28 \pm 0.12 \mathrm{~b}$ & $-2.69 \pm 0.01 \mathrm{~b}$ & $10.09 \pm 0.02 \mathrm{~d}$ & $92.32 \pm 0.12 \mathrm{~b}$ & $-2.55 \pm 0.02 \mathrm{a}$ & $9.98 \pm 0.02 \mathrm{c}$ \\
$15 \%, 160^{\circ} \mathrm{C}$ & $92.12 \pm 0.04 \mathrm{~b}$ & $-2.58 \pm 0.01 \mathrm{a}$ & $10.17 \pm 0.0 \mathrm{c}$ & $92.24 \pm 0.03 \mathrm{~b}$ & $-2.79 \pm 0.04 \mathrm{c}$ & $11.87 \pm 0.24 \mathrm{a}$ \\
\hline
\end{tabular}

Values expressed as mean \pm standard deviation. The same small letters in the same column indicate no significant difference (p>0.05). 
After spray drying, the concentrations of inulin, glucose and fructose decreased significantly $(p<0.05)$ with increasing concentrations of the encapsulant agent (Table 3). However, at higher drying temperatures at the same concentration of carrier agent, there was a significant decrease $(p<0.05)$ of inulin concentration and a significant increase $(p<0.05)$ of glucose and fructose concentrations.

Böhm, Kleessen and Henle (2006) observed that the heating of inulin from Jerusalem artichoke to $195^{\circ} \mathrm{C}$ induced degradation of fructan chains, whereas products of low molar mass were detected, probably di-D-fructose dianhydrides (DFDAs). Studies on the inulin obtained from chicory roots and subjected to temperatures between 135 and $195^{\circ} \mathrm{C}$ for $60 \mathrm{~min}$ indicated that between 20 and $100 \%$ of long-chain inulin were hydrolyzed in compounds such as glucose, fructose and sucrose (Böhm et al., 2005). This indicates that thermolysis of inulin should be considered when it is intended to be used as an ingredient in heat-treated prebiotic foods.

Lago et al. (2012) reported that after air drying at $70{ }^{\circ} \mathrm{C}$, the inulin content of both encapsulated yacon pulp and juice decreased significantly, while fructose and glucose concentrations increased significantly.

\section{Scanning electronic microscopy}

The particles obtained by spray drying (Figure 1) had distinct morphologies. The drying at $140{ }^{\circ} \mathrm{C}$ resulted in particles with spherical surfaces and some of them with concavities (Figure 1 A, B, E) and roughness (Figure 1 F). At $160{ }^{\circ} \mathrm{C}$, the particles presented spherical surfaces and were convex-concave (Figure 1 C, D, G, H). Spray-drying materials are usually hollow spheres, and the formation of concavities originates from the shrinking process that results from the hardening of the outer surface of the sphere and subsequent expansion of the air bubbles trapped inside the particle. In addition, the extent of depression observed in the microcapsules produced by spray drying is dependent of the nature of the carrier agent used and is significant for samples covered with polysaccharides (Tonon et al., 2009).

The increase of temperature favors the appearance of particles with less surface roughness, which can enhance the flow characteristics of the material (Tonon et al., 2009). At higher temperatures, water evaporates more rapidly, and the surface becomes dry and rigid, preventing the particles from shrinking, resulting in a more uniform structure (Nijdam; Langrish, 2005).

In Figure 1F, the particles observed presented a rough surface. The formation of these microstructures is undesirable, since it affects the flow properties of the material. Surface imperfections, such as roughness, cracks or collapse, occur when there is a slow process of film formation during drying of atomized droplets; the increase of the drying temperature, in turn, increases the rate of film formation on the drop surface (Rosenberg; Kopelman; Talmon, 1985; Ré, 1998).

It can be also observed that the smaller particles tended to agglomerate around the larger ones. The same behavior was observed for the powder obtained from the pulp and the juice of yacon encapsulated with native starch, and dried in hot air at $70{ }^{\circ} \mathrm{C}$ (Lago et al., 2012). This phenomenon probably occurred by high hygroscopicity of particles that were dried and have low humidity values. Bhandari, Data and Howes (1997) reported that during the spray drying of materials with a high sugar level, the product obtained may have amorphous surfaces since the characteristics of the material depends on drying conditions and product characteristics. According to Cano-Chauca et al. (2005), the presence of few superficial cracks or pores and the strong adhesion of smaller particles around the largest ones demonstrate absence of crystalline surfaces, which is a characteristic of amorphous products.

From these observations, it can be stated that the best encapsulation was observed with the FOS from UF-

Table 3: Sugar concentration (g/100g d.m.) in encapsulated powder from the permeate of yacon extract.

\begin{tabular}{rrrrrrr}
\hline \multirow{2}{*}{ Treatment } & \multicolumn{5}{c}{ UF-10 } & \multicolumn{3}{c}{ UF-30 } \\
\cline { 2 - 6 } & Inuline & \multicolumn{1}{c}{ Glucose } & \multicolumn{1}{c}{ Fructose } & Inuline & \multicolumn{1}{c}{ Glucose } & \multicolumn{1}{c}{ Fructose } \\
\hline $10 \%, 140^{\circ} \mathrm{C}$ & $7.23 \pm 0.10 \mathrm{a}$ & $7.04 \pm 0.01 \mathrm{C}$ & $13.12 \pm 0.01 \mathrm{~b}$ & $5.49 \pm 0.01 \mathrm{a}$ & $10.17 \pm 0.09 \mathrm{~b}$ & $12.94 \pm 0.20 \mathrm{~b}$ \\
$15 \%, 140^{\circ} \mathrm{C}$ & $5.75 \pm 0.05 \mathrm{~b}$ & $6.82 \pm 0.06 \mathrm{~d}$ & $9.17 \pm 0.09 \mathrm{~d}$ & $2.83 \pm 0.02 \mathrm{c}$ & $7.16 \pm 0.21 \mathrm{~d}$ & $8.02 \pm 0.12 \mathrm{~d}$ \\
$10 \%, 160^{\circ} \mathrm{C}$ & $4.71 \pm 0.04 \mathrm{c}$ & $12.65 \pm 0.10 \mathrm{a}$ & $16.85 \pm 0.32 \mathrm{a}$ & $4.55 \pm 0.00 \mathrm{~b}$ & $10.57 \pm 0.01 \mathrm{a}$ & $13.19 \pm 0.00 \mathrm{a}$ \\
$15 \%, 160^{\circ} \mathrm{C}$ & $4.58 \pm 0.02 \mathrm{~d}$ & $7.80 \pm 0.02 \mathrm{~b}$ & $10.58 \pm 0.01 \mathrm{c}$ & $2.73 \pm 0.02 \mathrm{~d}$ & $8.56 \pm 0.21 \mathrm{c}$ & $9.45 \pm 0.13 \mathrm{c}$ \\
\hline
\end{tabular}

Values expressed as mean \pm standard deviation. The same small letters in the same column indicate no significant difference $(p>0.05)$. 
30 , employing $10 \%$ gum arabic and dried at $160{ }^{\circ} \mathrm{C}$, which resulted in particles with smoother surfaces and smaller concavities when compared to the other treatments.

In this study, the atomization of samples without the addition of encapsulant agent was not possible due to the high concentrations of glucose and fructose (as shown in Table 3), and also other reducing sugars. These sugars, particularly fructose, are known for their hygroscopicity, which may result in highly hygroscopic products, reducing process yield (Davis, 1995). Therefore, it was essential to use a carrier agent with high molecular mass before atomization, to facilitate the drying process, the transport operations and storage, as also described by Bhandari, Data and Howes (1997).

\section{Prebiotic activity}

The prebiotic activity scores, obtained from the cell density values of the three different bacteria tested are shown in Figure 2.

For L. acidophilus LA-5 (Figure 2A), prebiotic activity scores observed for the permeate and retentate (treatments V and VI) of both UF-10 and UF-30 membranes were not significantly different $(p>0.05)$ to that obtained with glucose (treatment VII; control). These results are in agreement with those described by Kaplan and Hutkins (2000), who compared the metabolism of probiotic strains of Bifidobacterium infantis 17930 and Lactobacillus acidophilus NCFM with respect to three carbohydrates
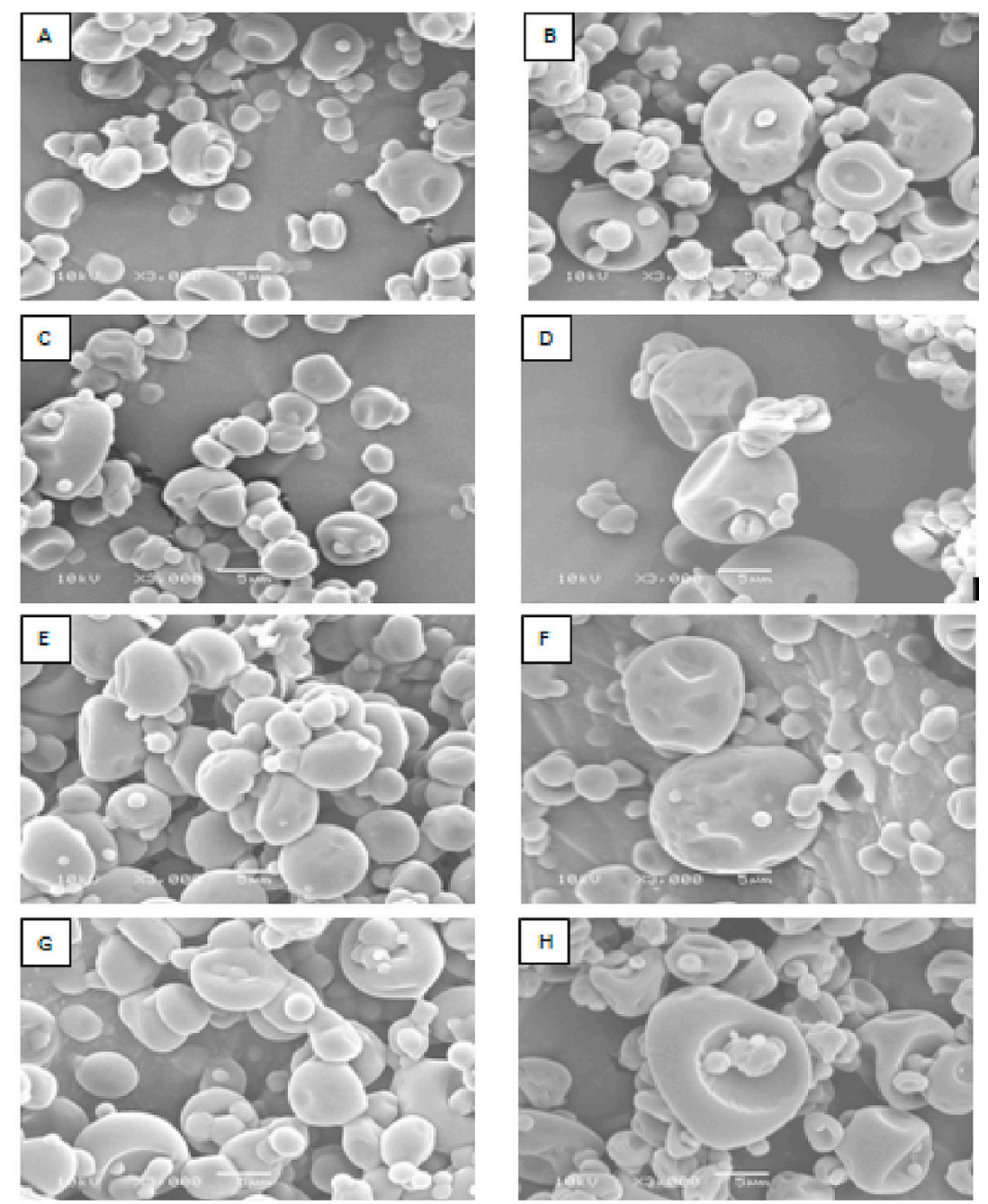

Figure 1: Microscopic images with magnification $\times 3000$ of the spray-dried powder permeate from UF-10 at $140^{\circ} \mathrm{C}$ and $10 \%$ gum arabic (A), $15 \%$ gum arabic (B) $160^{\circ} \mathrm{C}$ with $10 \%$ gum arabic (C), $15 \%$ gum arabic (D) coming permeate from UF-30 to $140{ }^{\circ} \mathrm{C}$ at $10 \%$ gum arabic $(\mathrm{E}), 15 \%$ gum arabic $(\mathrm{F}), 160^{\circ} \mathrm{C}$ at $10 \%$ gum arabic $(\mathrm{G}), 15 \%$ gum arabic $(\mathrm{H})$. 
(glucose, commercial FOS and 40\% FOS), and found that FOS and glucose resulted in similar increase in cell density. The encapsulated (I to IV) samples from UF-30 membrane were metabolized by strain LA- 5 in a similar manner to glucose, without significant differences $(p>0.05)$. For the UF-10 membrane, this effect was not observed since the encapsulated samples were less metabolized and scores were significantly different $(p<0.05)$ from glucose.
For B. lactis BB-12 (Figure 2B), no significant differences $(p>0.05)$ were observed for samples from permeate and retentate (V and VI) with respect to glucose (VII). When compared to the encapsulated samples, they were less metabolized and significantly different $(p<0.05)$ from glucose. Higher scores of prebiotic activity were observed for strain BB-12 when compared to LA-5. However, LA-5 metabolized the atomized samples from
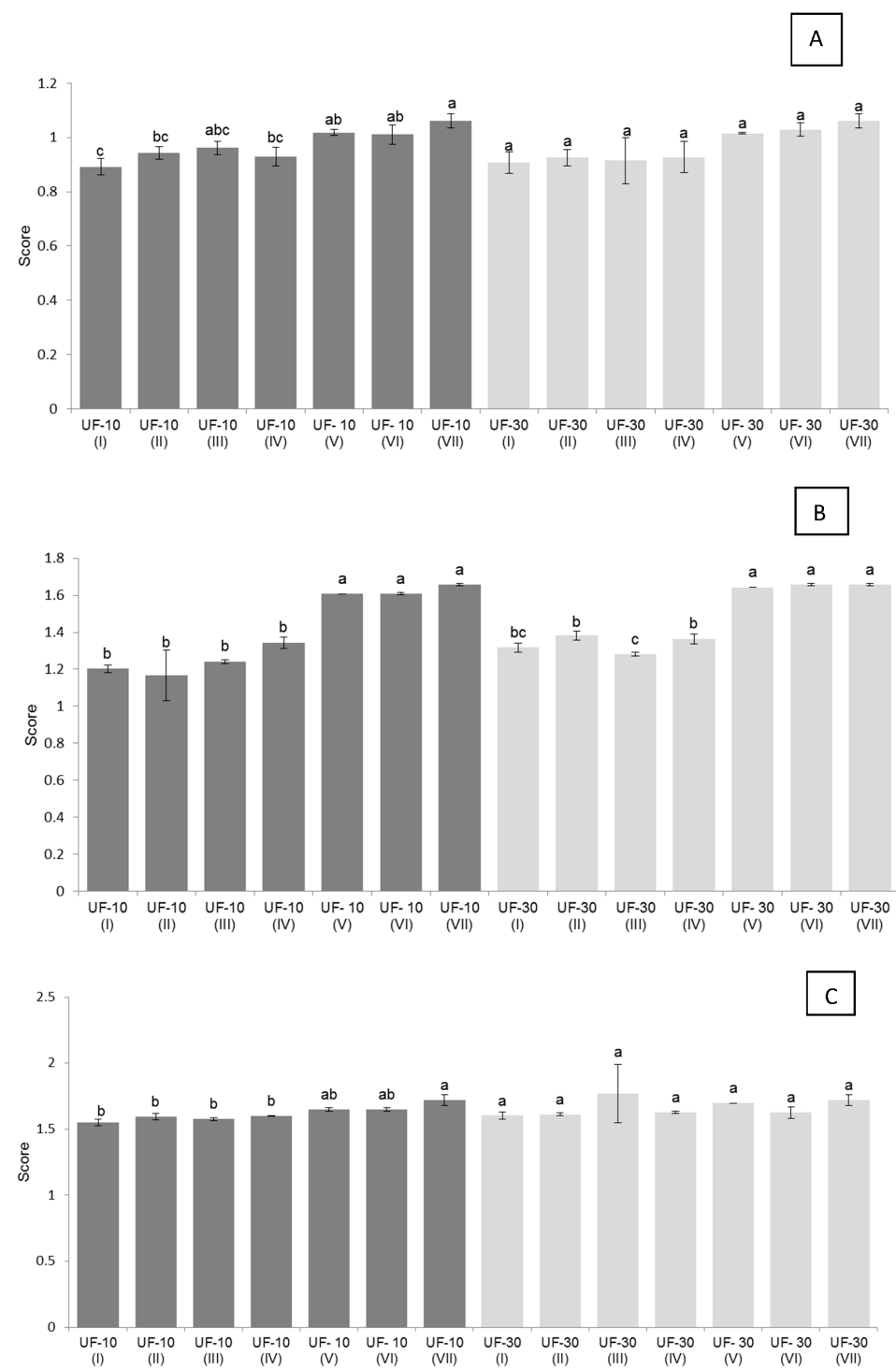

Figure 2: Prebiotic activity score for the multiplication of Lactobacillus acidophilus LA-5 (A), Bifidobacterium lactis BB-12 (B), and E. coli ATCC 25922 (C) in different treatments. (I) $10 \%$ gum arabic, $140{ }^{\circ} \mathrm{C}$; (II) $15 \%$ gum arabic, $140^{\circ} \mathrm{C}$; (III) $10 \%$ gum arabic, $160{ }^{\circ} \mathrm{C}$; (IV) $15 \%$ gum arabic, $160{ }^{\circ} \mathrm{C}$; (V) permeate without atomization; (VI) retentate without atomization; (VII) glucose.

* Different small letters indicate a significant difference $(p<0.05)$ between treatments for the same membrane. 
UF-30 membrane similarly to the glucose fermentation, indicating a potential prebiotic activity.

Huebner, Wehling and Hutkins (2007) tested five commercial prebiotics against ten probiotic strains. They reported that for most strains tested, growth in the presence of prebiotics was lower than growth in the presence of glucose. In addition, some studies demonstrated that the ability of bacteria of the genus Lactobacillus and Bifidobacterium to ferment prebiotic carbohydrates is specific regarding both strain and substrate (Kaplan; Hutkins, 2000).

Pedreschi et al. (2003) evaluated the ability of three probiotic strains to ferment FOS obtained from yacon extract and compared with commercial FOS (NutraFlora). The results indicate that $L$. acidophilus NRRL B-1910, L. plantarum NRRL B-4496 and B. bifidum ATCC 15696 were capable of fermenting yacon root FOS, and FOS consumption depended on the initial composition and degree of polymerization. They also observed that $L$. plantarum NRRL B-4496 and L. acidophilus NRRL B-1910 completely used the molecules of 1-kestose while B. bifidum was able to use 1-kestose, as well as molecules with a higher degree of polymerization. Sousa et al. (2015a) also found that yacon tuber flour had a potential prebiotic activity upon the growth of two Enterococcus strains, with validated safety and probiotic potential, and several commercial probiotic strains. These authors mentioned that this behaviour is probably attributed to the FOS content in yacon, which enhanced the probiotic bacteria growth and metabolism, and resulted in the increase of short chain organic acids production.

Wichienchot, Jatupornpipat and Rastall (2010) used oligosaccharides extracted from dragon fruit as carbon sources for the culture of probiotic strains of Lactobacillus delbrueckii BCC 13296 and B. bifidum NCIMB 702715. The oligosaccharides stimulated the growth from $9.02 \times 10^{7}$ to $6.17 \times 10^{9}$ cells $/ \mathrm{mL}$ and $1.70 \times 10^{8}$ to $2.51 \times 10^{9}$ cells/ $\mathrm{mL}$, respectively. Inulin also stimulated the growth of $L$. delbrueckii BCC 13296, but its effect was significantly lower $\left(8.24 \times 10^{8}\right.$ cells $\left./ \mathrm{mL}\right)$. For B. bifidum NCIMB 702715 , inulin had a greater effect $\left(2.76 \times 10^{9}\right.$ cells $\left./ \mathrm{mL}\right)$, but no significant difference was observed when compared to the oligosaccharides extract.

With respect to $E$. coli (Figure 2 C), no significant differences $(p>0.05)$ were observed for permeate and retentate samples (V and VI) from both UF membranes, with respect to glucose. For encapsulated samples from the UF-10, the multiplication of this bacteria was lower than the multiplication on glucose $(p<0.05)$. Huebner et al. (2008) mentioned that a good prebiotic substrate should have the ability to be selective and not fermented by intestinal pathogens. However, enterobacteria are predominant facultative anaerobic bacteria present in the ileum and colon, contributing significantly to the fermentation of FOS (Mitsuoka; Hidaka; Eida, 1987). Some commercial prebiotics stimulate the multiplication of enteric bacteria in the same form or even higher than for probiotic strains (Huebner; Wehling; Hutkins, 2007).

Hartemink, Vanlaere and Rombouts (1997) studied the multiplication of 35 strains of enterobacteriaceae, including 13 different strains of $E$. coli on different substrates (Raftilose P95, Profeed P95, Raftiline LS, and glucose). E. coli multiplied rapidly in media with glucose, without difference in cell yield between the strains using this substrate. Among the strains tested, seven were able to grow in Raftiline LS (inulin), but the degradation of this substrate was low because a significant decrease of $\mathrm{pH}$ values was not observed. The hydrolysis of prebiotic carbohydrates often results in the formation of sucrose, glucose and fructose, which do not offer a selective stimulation of probiotic strains (Huebner et al., 2008).

In this way, the products developed in this work may be used as ingredients or supplements by the food industry, since they present functional properties such as prebiotic, bioactive, low-glycemic sweetener, anti-motility, fiber and appetite suppressing. However, additional studies in vitro must be realized.

\section{CONCLUSIONS}

The permeate of yacon samples encapsulated under different concentrations of gum arabic and different drying temperatures showed solubility values greater than $90 \%$ and the hygroscopicity decreased with increasing gum concentration and drying temperature. The use of high temperatures in spray drying diminished the content of inulin, probably by thermolysis leading to the degradation of these chains, thereby increasing the levels of glucose and fructose. The concentrations of inulin obtained after spray-drying were in the range from 2.73 to 7.23 (g/100 g d.m.) in encapsulated powder. The scores of prebiotic activity for $L$. acidophilus LA-5 and B. lactis BB-12 showed no differences between the permeate and retentate samples with respect to controls. The samples encapsulated from membrane UF-30 were metabolized in a similar manner to glucose by culture LA-5. However, for the BB-12, all encapsulated samples showed significantly lower scores respective to glucose. These results indicate that the powder extract of yacon obtained in this work are an interesting source of prebiotic FOS. 


\section{ACKNOWLEDGMENTS}

This work was supported by the Brazilian agencies CNPq, CAPES and FAPERGS.

\section{REFERENCES}

ALI, B. H.; ZIADA, A.; BLUNDEN, G. Biological effects of gum arabic: A review of some recent research. Food and Chemical Toxicology. 47(1):1-8, 2009.

ASSOCIATION OF OFFICIAL ANALYTICAL CHEMISTRY - AOAC. Official Methods of Analysis. 15.ed. Washington, DC: 987-988. 1990.

BHANDARI, S. R.; DATA, N.; HOWES, T. Problems associated with spray drying of sugar-rich foods. Drying Technology. 15(2):671-684, 1997.

BÖHM, A. et al. Heat-induced degradation of inulin. European Food Research and Technology. 220(5):466-471, 2005.

BÖHM, A.; KLEESSEN, B.; HENLE, T. Effect of dry heated inulin on selected intestinal bacteria. European Food Research and Technology. 222(5-6):737-740, 2006.

CANO-CHAUCA, M. et al. Effect of the carriers on the microstructure of mango powder obtained by spray drying and its functional characterization. Innovative Food Science \& Emerging Technologies. 6(4):420-428, 2005.

CARNEIRO, H. C. F. et al. Encapsulation efficiency and oxidative stability of flaxseed oil microencapsulated by spray drying using different combinations of wall materials. Journal of Food Engineering. 115(4):443-451, 2013.

CASTRO, A. et al. Dietary fiber, fructooligosaccharides, and physicochemical properties of homogenized aqueous suspensions of yacon (Smallanthus sonchifolius). Food Research International. 50(1):392-400, 2013.

DAVIS, E. Functionality of sugars: Physicochemical interactions in foods. American Journal of Clinical Nutrition. 62(1):170S-177S, 1995.

FAZAELI, M. et al. Effect of spray drying conditions and feed composition on the physical properties of black mulberry juice powder. Food and Bioproducts Processing. 90(4):667-675, 2012.

FRANCO, T. S. et al. Effects of foam mat drying on physicochemical and microstructural properties of yacon juice powder. LWT - Food Science and Technology. 66:503-513, 2016.
FRANCO, T. S. et al. Foam mat drying of yacon juice: Experimental analysis and computer simulation. Journal of Food Engineering. 158:48-57, 2015.

HARTEMINK, R.; VANLAERE, K. M. J.; ROMBOUTS, F. M. Growth of enterobacteria on fructo-oligosaccharides. Journal of Applied Microbiology. 83:367-374, 1997.

HUEBNER, J.; WEHLING, R. L.; HUTKINS, R. W. Functional activity of commercial prebiotics. International Dairy Journal. 17(7):770-775, 2007.

HUEBNER, J. et al. Effect of processing conditions on the prebiotic activity of commercial prebiotics. International Dairy Journal. 18(3):287-293, 2008.

KAMADA, T. et al. Availability of membrane technology for purifying and concentrating oligosaccharides. European Food Research and Technology. 214(5):435-440, 2002a.

KAMADA, T. et al. Pilot-scale study of the purification and concentration of non-digestible saccharides from yacon rootstock using membrane technology. Food Science and Technology Research. 8(2):172-177, 2002b.

KAPLAN, H.; HUTKINS, R.W. Fermentation of fructooligosaccharies by lactic acid bacteria and bifidobacteria. Applied and Environmental Microbiology. 66(6):2682-2684, 2000.

LACHMAN, J.; FERNÁNDEZ, E. C.; ORSÁK, M. Yacon [Smallanthus sonchifolia (Poepp. et Endl.) H. Robinson] chemical composition and use - a review. Plant Soil Environment. 49(6):283-290, 2003.

LAGO, C. C. et al. Characterization of powdered yacon (Smallanthus sonchifolius) juice and pulp. Food and Bioprocess Technology. 5(6):2183-2191, 2012.

MITSUOKA, T.; HIDAKA, H.; EIDA, T. Effect of fructooligosaccharides on intestinal microflora. Die Nahrung. 31(5-6):427-436, 1987.

MATUSEK, A. et al. Fructo-oligosaccharide degradation in apple pulp matrix. Acta Alimentaria, 40(2):182-193, 2011.

NIJDAM, J. J.; LANGRISH, T. A. G. An investigation of milk powders produced by a laboratory-scale spray dryer. Drying Technology. 23(5):1043-1056, 2005.

OJANSIVU, I.; FERREIRA, C. L.; SALMINEN, S. Yacon, a new source of prebiotic oligosaccharides with a history of safe use. Food Science and Technology. 22(1):40-46, 2011.

PEDRESCHI, R. et al. Andean yacon root (Smallanthus sonchifolius Poepp. Endl) fructooligosaccharides as a potential novel source of prebiotics. Journal of Agricultural and Food Chemistry, 51(18):5278-5284, 2003. 
PSZCZOLA, D. Encapsulated ingredients: Providing the right fit. Food Technology. 52(12): 70-77, 1998.

QUEK, S. Y.; CHOK, N. K.; SWEDLUND, P. The physicochemical properties of spray-dried watermelon powders. Chemical Engineering and Processing. 46(5):386-392, 2007.

RÉ, M. I. Microencapsulation by spray drying. Drying Technology. 16(6):1195-1236, 1998.

RISCH, S. J.; REINECCIUS, G. A. Encapsulation and controlled release of food ingredients. Washington, DC: American Chemical Society (ACS), 214p, 1995.

ROOS, Y. Melting and glass transition of low molecular weight carbohydrates. Carbohydrate Research. 238(1):39-48, 1993.

ROSENBERG, M.; KOPELMAN, I. J.; TALMON, Y. A scanning electron microscopy study of microencapsulation. Journal of Food Science. 50(1):139-144, 1985.

SAÉNZ, C. et al. Microencapsulation by spray drying of bioactive compounds from cactus pear (Opuntiaficus indica). Food Chemistry. 114(2):616-622, 2009.

SHOAIB, M. et al. Inulin: properties, health benefits and food applications. Carbohydrate Polymers. 147:444-454, 2016

SOUSA, S. et al. In vitro evaluation of yacon (Smallanthus sonchifolius) tuber flour prebiotic potential. Food and Bioproducts Processing. 95:96-105, $2015 a$.

SOUSA, S. et al. Antioxidant properties of sterilized yacon (Smallanthus sonchifolius) tuber flour. Food Chemistry. 188:504-509, 2015b.

TAKENAKA, M. et al. Caffeic acid derivatives in the roots of yacon (Smallanthus sonchifolius). Journal of Agricultural and Food Chemistry. 51(3):793-796, 2003.

TÓFANO, J. et al. Optimization of a physical concentration process for inulin. Journal of Food Engineering. 80(3):832$838,2007$.
TONELI, J. T. C. L. et al. Effect of moisture on the microstructure of inulin powder. Food Science and Technology. 28(1):122131, 2008.

TONON, R. V. et al. Physicochemical and morphological characterisation of açaí (Euterpe oleraceae Mart.) powder produced with different carrier agents. International Journal of Food Science and Technology. 44(10):1950-1958, 2009.

UTAMI, N. W. A. et al. Comparison of yacon (Smallanthus sonchifolius) tuber with commercialized fructooligosaccharides (FOS) in terms of physiology, fermentation products and intestinal microbial communities in rats. Bioscience of Microbiota, Food and Health. 32(4):167178, 2013.

VAZ-TOSTES, M. G. et al. Yacon effects in immune response and nutritional status of iron and zinc in preschool children. Nutrition. 30(6):666-672, 2014.

VEGA-GÁLVEZ, A. et al. Effect of air-drying temperature on physico-chemical properties, antioxidant capacity, colour and total phenolic content of red pepper (Capsicum annuum L. var. Hungarian). Food Chemistry. 117(4):647-653, 2009.

WICHIENCHOT, S.; JATUPORNPIPAT, M.; RASTALL, R. A. Oligosaccharides of pitaya (dragon fruit) flesh and their prebiotic properties. Food Chemistry. 120(3):850-857, 2010.

ZIMERI, J. E.; KOKINI, J. L. The effect of moisture content ion the crystallinity and glass transition temperature of inulin. Carbohydrate Polymers. 48(3):299-304, 2002.

ZHU, Z. Y. et al. Comparative evaluation of polysaccharides isolated from Astragalus, oyster mushroom, and yacon as inhibitors of a-glucosidase. Chinese Journal of Natural Medicines. 12(4):290-293, 2014.

ZULETA, A.; SAMBUCETTI, M. Inulin determination for food labeling. Journal of Agricultural and Food Chemistry. 49(10):4570-4572, 2001. 